\title{
Expression of precerebellins in cultured rat calvaria osteoblast-like cells
}

\author{
MARCIN RUCINSKI $^{1}$, AGNIESZKA ZOK ${ }^{1}$, DIEGO GUIDOLIN ${ }^{2}$, \\ RAFFAELE DE CARO ${ }^{2}$ and LUDWIK K. MALENDOWICZ ${ }^{1}$
}

\author{
${ }^{1}$ Department of Histology and Embryology, University of Medical Sciences, PL-60781 Poznan, Poland; \\ ${ }^{2}$ Department of Anatomy and Physiology, Section of Anatomy, University of Padova, I-35121 Padova, Italy
}

Received April 15, 2008; Accepted May 26, 2008

DOI: 10.3892/ijmm_00000055

\begin{abstract}
Cerebellin (CER), originally isolated from rat cerebellum, is a hexadecapeptide derived from the larger precursor called precerebellin 1 (Cbln 1$)$. At present 4 propeptides designated as Cbln1, Cbln2, Cbln3 and Cbln4 are recognized. They belong to precerebellin subfamily of the $\mathrm{C}_{1} \mathrm{q}$ family proteins. Precerebellins act as transneuronal regulators of synapse development and synaptic plasticity in various brain regions. Initially CER was thought to be a cerebellum specific peptide, however subsequent studies revealed its presence in other brain regions as well as in extraneuronal tissues. We investigated whether precerebellins are expressed and involved in regulation of cultured rat calvarial osteoblast-like (ROB) cells. Classic RT-PCR revealed the presence of Cbln1 and Cbln3 mRNA in fragments of rat calvaria, in freshly isolated ROB cells and in ROB cells cultured for 7, 14 and 21 days. Cbln2 and Cbln4 mRNA, on the other hand, could not be demonstrated in ROB cells but was found to be present in the brain. In freshly isolated ROB cells expression of Cbln 1 gene was very low and gradually increased in relation to the duration of culture. Expression of Cbln3, on the other hand, was very low in fragments of rat calvaria, and increased notably after digestion with collagenase-I. The highest expression of this precerebellin was observed at day 14 of culture while at days 7 and 21 levels of expressions were notably lower. Neither Cbln2 nor Cbln 4 was found to be expressed in the ROB cells. Neither CER nor des-Ser-CER $\left(10^{-10}-10^{-6} \mathrm{M}\right)$ affect osteocalcin production and proliferation rate of studied cells. The above findings suggest that CER, which theoretically would be derived from Cbln1, modulate neither differentiated (osteocalcin secretion) nor
\end{abstract}

Correspondence to: Professor Ludwik K. Malendowicz, Department of Histology and Embryology, Poznan University of Medical Sciences, 6 Swiecicki St., 60-781 Poznan, Poland

E-mail:1km@amp.edu.pl

Key words: cerebellin, precerebellins, quantitative PCR, osteocalcin, proliferation, rat osteoblasts, cell culture basic (proliferation) functions of cultured rat osteoblast-like cells. The obtained data raise an intriguing hypothesis that precerebellins may be involved in regulating of spatial organization of osteoblastic niches in the bone.

\section{Introduction}

Cerebellin (CER), originally isolated from rat cerebellum, is a hexadecapeptide derived from the larger precursor called precerebellin 1 (Cbln1) $(1,2)$. Initially CER was thought to be a cerebellum specific peptide, however, subsequent studies revealed its presence in other brain regions as well as in extraneuronal tissues. At present 4 propeptides designated as Cbln1, Cbln2, Cbln3 and Cbln4 are recognized (3-6). Their nucleotide sequences are highly homologous, moreover entire family of precerebellins demonstrates high homology to the family of atypical solluble collagens (types VII and X) $(7,8)$ as well as to A, B and C subunits of the component complex $\mathrm{C}_{1} \mathrm{q}$ (9-11). Cbln1-Cbln4 are highly expressed in the brain and recent data suggest that the family of cbln proteins acts as transneuronal regulators (transneuronal) of synapse development and synaptic plasticity in various brain regions $(6,12)$.

Apart from the central nervous system, precerebellins are also expressed at periphery. Immunoreactive CER was reported to be present in the alimentary tract, heart and kidney of the rat and guinea pig and in normal and pathological human adrenals $(4,13,14)$. Those earlier observations were confirmed and extended by means of molecular biology techniques (6). At the mRNA and/or protein level expression of Cbln1 was found in testes, ovaries, adrenals and pancreatic islets, Cbln2 in testes and Cbln 3 in testes, ovaries and adrenals $(5,6,15)$.

It has been reported that numerous neuropeptides acting via endocrine, paracrine or autocrine routes and through the nervous system regulate biological activity of the major bone cell types. To this class of biologically active peptides among others belong arginine-vasopressin, substance P, VIP, PACAP, GIP, leptin, ghrelin and neuro-medin U (16-29). The present study aimed to investigate whether CER may be included into the class of bone regulating peptides. To address this issue, on cultured rat calvaria osteoblast-like (ROB) cells we studied expression of precerebellins and we 
Table I. QPCR analysis of precerebellins (Cbln1-4) and HPRT (hypoxanthine-guanine phosphoribosyl transferase) mRNAs in cultured rat calvarial osteoblast-like (ROB) cells. ${ }^{a}$

\begin{tabular}{|c|c|c|c|c|c|}
\hline cDNA & $\begin{array}{c}\text { Genbank } \\
\text { accession no. }\end{array}$ & Primers & Primer sequence $\left(5^{\prime}-3^{\prime}\right)$ & Position & $\begin{array}{l}\text { PCR product } \\
\text { size (bp) }\end{array}$ \\
\hline \multirow[t]{3}{*}{ Cbln1 } & XM 001067551 & $\mathrm{~S}$ & CCCTACGGGCACTGCTCTG & 144-162 & 171 \\
\hline & & A & CTGCGTTCTGAGTCAAAGTTG & 294-314 & \\
\hline & & probe & CTGCCATC & 203-210 & \\
\hline \multirow[t]{3}{*}{ Cbln2 } & NM 001012740 & $\mathrm{~S}$ & TGGCCTTCTCCGCTACTC & $457-474$ & 119 \\
\hline & & A & CGAGGCAAGGTCAAAGTGGT & $556-575$ & \\
\hline & & probe & TGAGCAAC & $502-509$ & \\
\hline \multirow[t]{3}{*}{ Cbln3 } & XM 001056593 & $\mathrm{~S}$ & ACCATGAACCAGCAGGAGAA & $483-502$ & 86 \\
\hline & & A & AAAGCCACCGCCCTCATT & $551-568$ & \\
\hline & & probe & TGCGATCT & $523-531$ & \\
\hline \multirow[t]{3}{*}{ Cbln4 } & ХM 001053640 & $S$ & GAGCAACAAGACTCGCATCAT & 1859-1879 & 80 \\
\hline & & A & CAAAGACGGATTCCAGTGTG & $1919-1938$ & \\
\hline & & probe & CTGGTTAA & $1896-1903$ & \\
\hline \multirow[t]{3}{*}{ HPRT } & NM 012583 & $S$ & CAGTCAACGGGGGACATAAAAG & $391-412$ & 146 \\
\hline & & A & ATTTTGGGGCTGTACTGCTTGA & $515-536$ & \\
\hline & & probe & CCTCATG & $451-457$ & \\
\hline
\end{tabular}

${ }^{a}$ Oligonucleotide sequences for sense (S) and antisense (A) primers, and for probes are shown. Also the sequence of the probes is shown.

tested effects of CER and des-Ser-CER (desCER) on proliferative activity and osteocalcin secretion by these cells.

\section{Materials and methods}

Animals and reagents. Two day-old Wistar rats, born in our animal facilities, were used. The local Ethics Committee for Animal Studies approved the study protocol. Cerebellin (CER) and desCER were purchased from Bachem AG, Bubendorf, Switzerland. If not otherwise stated, the reagents were obtained from Sigma-Aldrich (St. Louis, MO, USA) or from POCh (Gliwice, Poland).

Rat calvaria osteoblast-like ( $R O B)$ cell culture. The technique was that described earlier (30-34) with few modifications. Briefly, calvarias of eight 2-day-old rats were placed in DMEM (Gibco, UK), and the connective tissue was removed. Calvarias were then cut into small fragments, which were digested with $0.1 \%$ collagenase-I (Sigma-Aldrich) for $30 \mathrm{~min}$ at $37^{\circ} \mathrm{C}$. ROB cells were harvested by centrifugation and resuspended in DMEM supplemented with $\mathrm{NaHCO}_{3}, 6 \%$ FCS (fetal calf serum) and antibiotic-antimycotic solution. Cells were then plated in culture dishes (Nalge Nunc International, Denmark, $1 \times 10^{4}$ cells/dish), and cultured for 21 days at $37^{\circ} \mathrm{C}$ in an humidified atmosphere of $95 \%$ air-5\% $\mathrm{CO}_{2}$, medium being changed every other day (34). The experiments were performed on freshly isolated cells before and after digestion (RT-PCR) and cells harvested at days 7, 14 and 21 of culture. Forty-eight hours before sampling cells were maintained in medium without FCS. In such medium osteoblasts were exposed for $48 \mathrm{~h}$ to various concentrations of CER and desCER.

Osteocalcin determination. Osteocalcin concentrations in the culture medium were estimated using a rat osteocalcin EIA kit (Biomedical Technologies Inc., Stoughton, MA, USA). The sensitivity of the assay was $0.5 \mathrm{ng} / \mathrm{ml}$, and inter- and intra-assay CVs: 7 and 4\%, respectively.

Cell proliferation. Proliferation rate of ROB cells was measured by the EZ4U Non-radioactive Cell Proliferation and Cytotoxic Assay kit (Biomedica, Vienna, Austria) (35). Cultured cells were incubated for 90 min with EZ4U, and the formazan derivative production, which is linearly related to the cell number, was measured at $490 \mathrm{~nm}$ wavelength in a microplate autoreader EL-13 (Bio-Tek Instruments, Winooski, VT, USA).

Conventional RT-PCR and $q P C R$. Methods applied were described earlier $(15,36-40)$. Total RNA from harvested cells and fragments of calvaria was extracted, by a method using TRI Reagent (Sigma) and purified on columns (Rneasy Mini Kit, Qiagen) $(15,41,42)$. Contaminating DNA was eliminated by DNase-I treatment (Rnase-Free DNase Set; Promega, Madison, WI), and the amount of total RNA was determined by measuring optical density at $260 \mathrm{~nm}$ and purity was estimated by $260 / 280 \mathrm{~nm}$ absorption ratio, which was consistently $>1.8$. RT was performed using Verte M-MLV reverse transcriptase 
(Novazym) with Oligo-dT (PE Biosystems, Warrington, UK) as primers. Reaction was performed at $42^{\circ} \mathrm{C}$ for $60 \mathrm{~min}$. Quality of obtained product was evaluated by electrophoresis in $1 \%$ agarose gel with etidium bromide. Applied primers for studies of precerebellin gene expression (Table I) were purchased from the Laboratory of DNA Sequencing and Oligonucleotide Synthesis, Institute of Biochemistry and Biophysics, Polish Academy of Sciences, Warsaw. HPRT (hypoxanthine-guanine phosphoribosyl transferase) gene was used as reference to normalize data.

To determine efficiency of target and reference qPCR reactions, for all studied genes and HPRT - [reference gene hypoxanthine guanine phosphoribosyltransferase (EC 2.4.2.8)] gene standard curves were prepared with the products of traditional RT-PCR reaction. These products were subsequently separated on 2\% agarose gel. Specific bands were extracted by DNA gel extraction kit (Millipore). Amount of extracted DNA was spectrophotometrically quantified. Standard curves were generated by dilution of isolated cDNA in 1:10 dilution steps.

QPCR was performed on Lightcycler 2.0 instrument (Roche) with software version 4.0. PCR product was detected by LNA probe hydrolysis from Universal Probe Library of Roche. They are labeled at the 5'-end with fluorescein (FAM) and at the 3 '-end with a dark quencher dye. Primers and probes were designed using ProbeFinder Version 2.33 of Roche. Each $20 \mu 1$ of reaction mixture contained: pair of specific primers at concentration of $0.5 \mu \mathrm{M}, 4 \mu 1$ of LightCycler TaqMan Master Mix, $0.5 \mu \mathrm{M}$ of gene specific probe and $4 \mu 1$ of cDNA sample (or standards and control reactions). Each sample was assayed in triplicate. The qPCR program included 10-min denaturation step to activate the Taq DNA polymerase followed by a three-step amplification program: denaturation step at $95^{\circ} \mathrm{C}$ for $10 \mathrm{sec}$, an annealing step at $56^{\circ} \mathrm{C}$ for $5 \mathrm{sec}$, and extension step at $72^{\circ} \mathrm{C}$ for $2 \mathrm{sec}$. Detection of the PCR amplicons was performed by size fractionation on $2 \%$ agarose gel electrophoresis.

Statistical analyses. Data are expressed as the means \pm SEM. Two-sample statistical comparisons were performed by the unpaired Student's t-test. When more than two groups were to be compared, one-way analysis of variance (ANOVA) was used, followed by the Tukey test for multiple comparisons. The analysis was performed by using the statistical package GraphPad Prism 3.02 (GraphPad Software Inc., San Diego, CA).

\section{Results}

Classic RT-PCR revealed the presence of Cbln1 and Cbln3 mRNA in fragments of rat calvaria, in freshly isolated ROB cells and in ROB cells cultured for 7, 14 and 21 days (Fig. 1). Cbln2 and Cbln 4 mRNA, on the other hand, could not be demonstrated in ROB cells but was found to be present in the brain. With specific primers RNA amplification by means of RT-PCR revealed the presence of reaction products with expected size: Cbln1, 171 bp; Cbln2, 119 bp; Cbln3, 86 bp; Cbln4, 80 bp.

As demonstrated in Fig. 2, in freshly isolated ROB cells expression of Cbln1 gene was very low but significantly

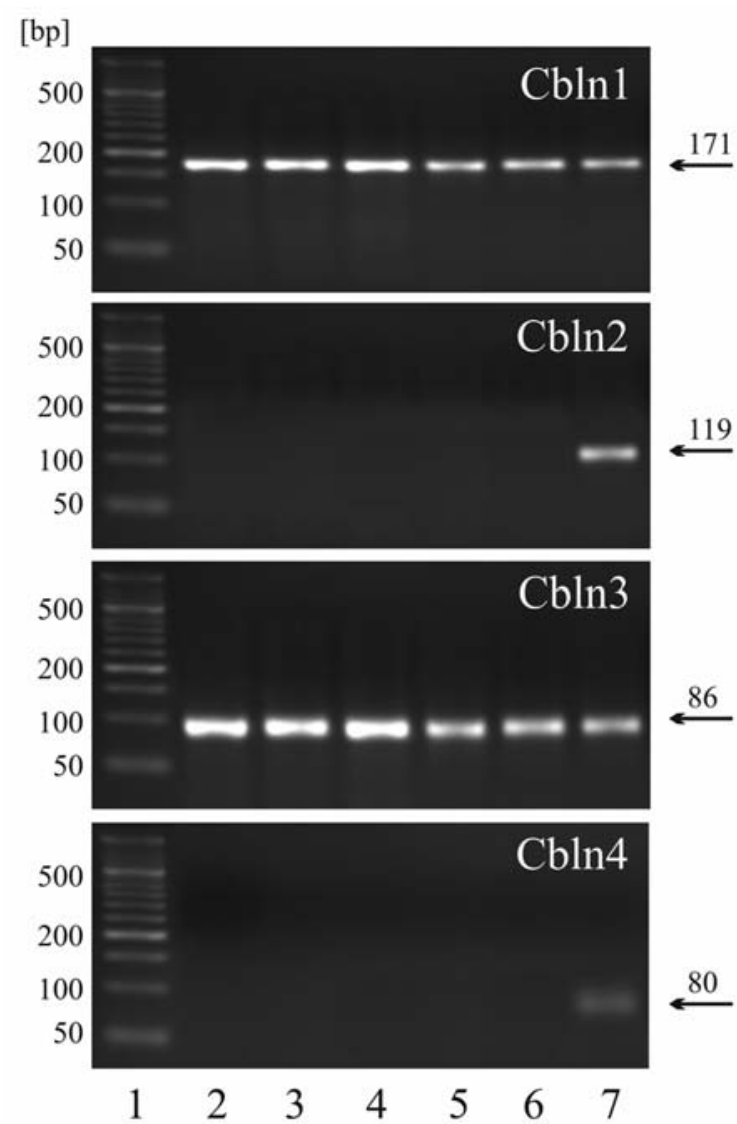

Figure 1. Ethidium bromide-stained $2 \%$ agarose gel showing cDNA amplified with rat specific primer from RNA of ROB cells cultured for 7, 14 and 21 days. Lane 1, size marker (O'Range Ruler 50-bp DNA Ladder; MBI Fermentas, Lithuania); lane 2, fragments of rat calvaria; lane 3, freshly isolated ROB cells; lane 4, day 7 of culture; lane 5, day 14 of culture; lane 6, day 21 of culture; lane 7, positive controls (cerebellum for Cbln1 and Cbln3; brain for Cbln2 and Cbln4). Reaction products with expected size are seen: Cbln1, 171 bp; Cbln2, 119 bp; Cbln3, 86 bp; Cbln4, 80 bp.

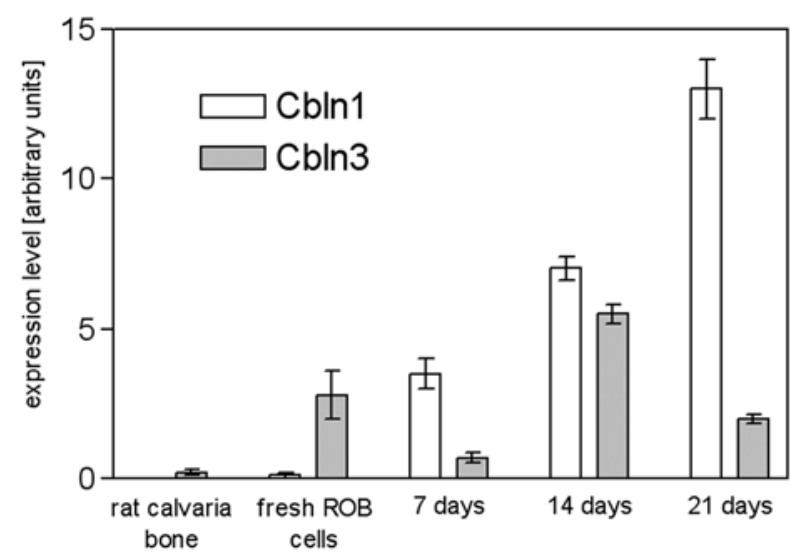

Figure 2. QPCR analyses of Cbln1 and Cbln3 gene expression in fragments of rat calvaria bone, in freshly isolated cells and in the ROB cells at day 7, 14 and 21 of culture, respectively. All samples were amplified in triplicate, and HPRT gene expression was used as reference to normalize data. Each group $n=3$.

increased (One-way ANOVA: $\mathrm{F}_{3,8}=85.46$, $\mathrm{p}<0.01$ ) in relation to the duration of culture (Fig. 2). Expression of Cbln3, on the other hand, was very low in fragments of rat calvaria, and 

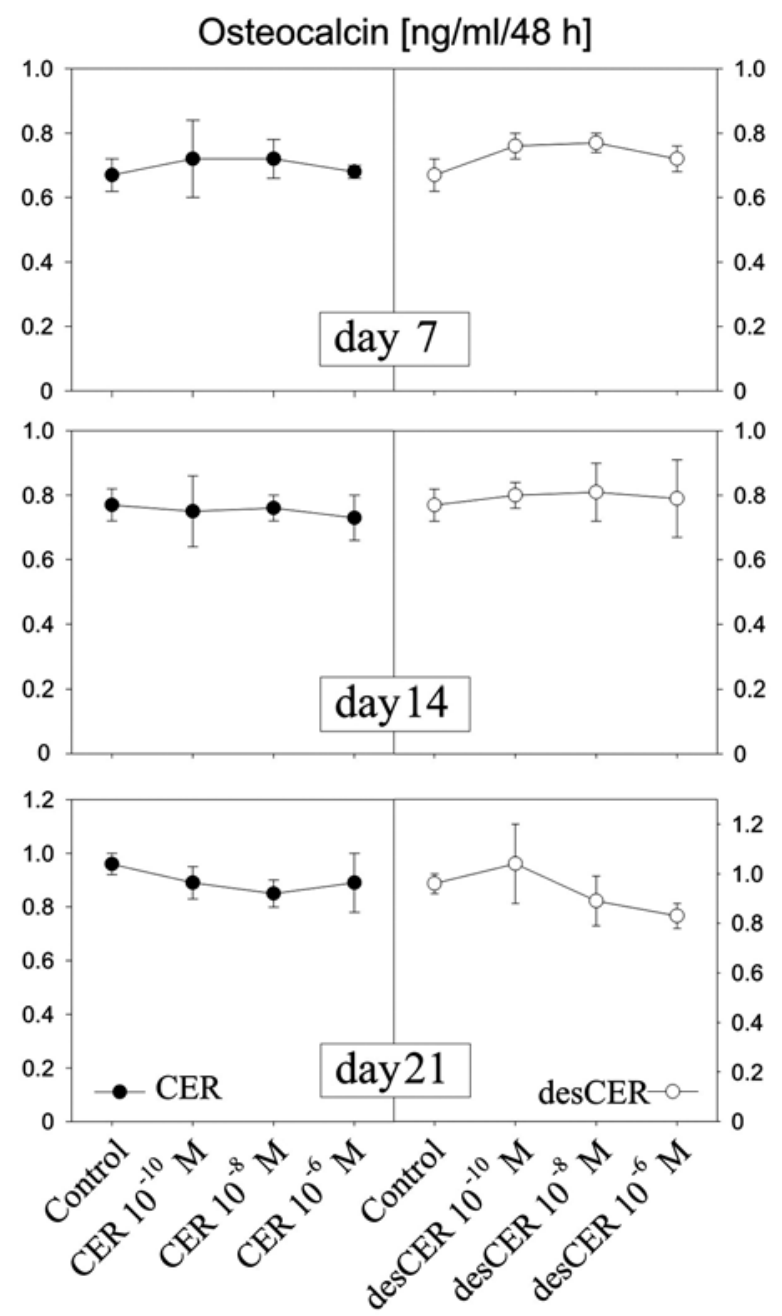

Figure 3. Effects of CER and desCER on osteocalcin secretion (ng/ml/48 h/ $1 \times 10^{5}$ cells) by cultured ROB cells. Cells were exposed to tested compounds for $48 \mathrm{~h}$ in FCS stripped of medium. Neuropeptides were added to culture $48 \mathrm{~h}$ before medium collection at days 7,14 and 21. Data are expressed as means \pm SEM, $n=6$. Statistical comparisons (in relation to control) were done by the unpaired Student's t-test - all differences statistically non-significant.

increased notably after digestion with collagenase-I. The highest expression of that precerebellin was observed at day 14 of culture while at days 7 and 21 levels of expression were significantly lower ( $\mathrm{p}<0.05$, Student's t-test). Neither Cbln2 nor Cbln4 were found to be expressed in the ROB cells.

To investigate whether CER or desCER affect osteocalcin production, cultured ROB cells were exposed for $48 \mathrm{~h}$ to various concentrations of neuropeptides $\left(10^{-10}-10^{-6} \mathrm{M}\right)$. Neither CER nor desCER changed osteocalcin concentrations in media analyzed at days 7, 14 and 21 of culture (Fig. 3). Likewise, both cerebellins did not change the proliferative activity of studied cells (Fig. 4).

\section{Discussion}

Data on expression of CER and CER mRNA outside the central nervous system are limited and controversial. In this study for the first time we demonstrated expression of Cbln1 and Cbln 3 at the mRNA level in freshly isolated and cultured

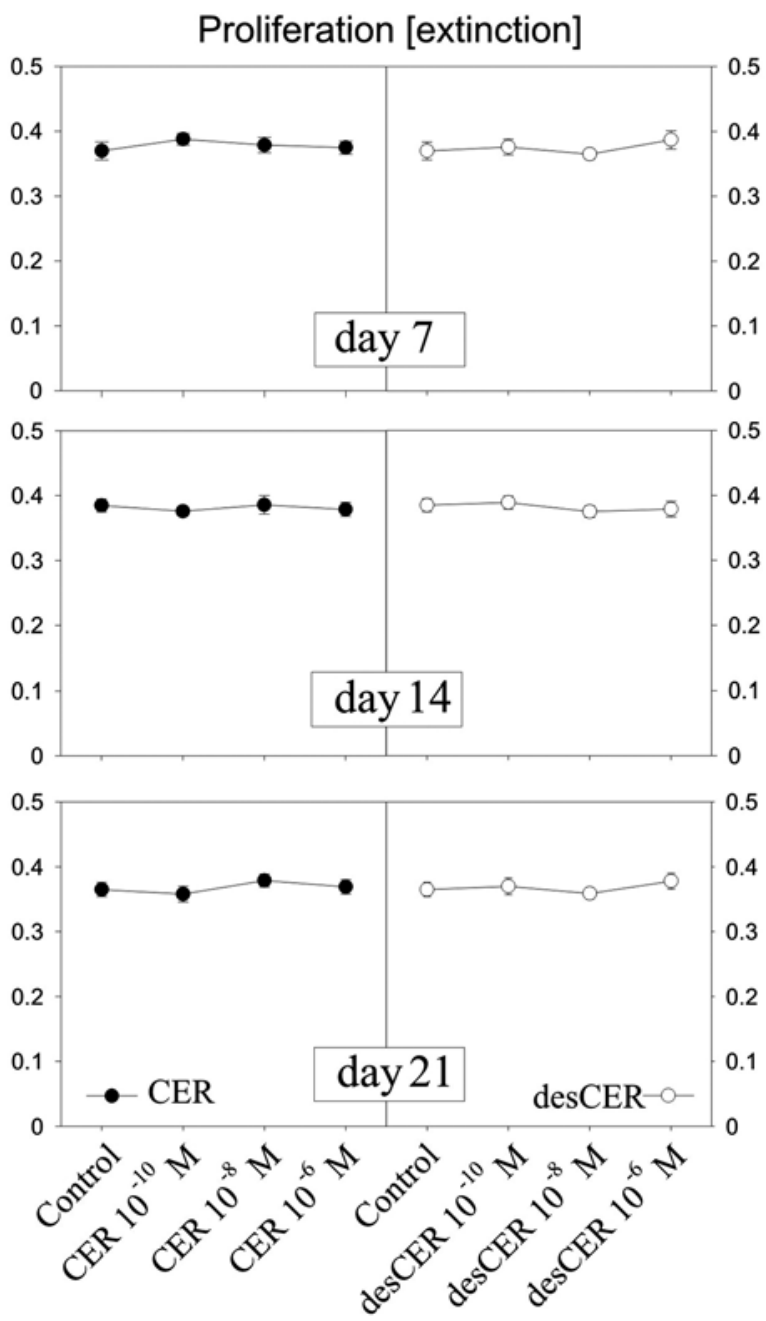

Figure 4. Effects of CER and desCER on proliferative activity (absorbance) of cultured ROB cells. Cells were exposed to tested compounds for $48 \mathrm{~h}$ in FCS stripped of medium. Neuropeptides were added to culture $48 \mathrm{~h}$ before medium collection at days 7,14 and 21. Data are expressed as means \pm SEM, $n=6$. Statistical comparisons (in relation to control) were done by the unpaired Student's t-test - all differences statistically non-significant.

ROB cells, while expression of the remaining precerebellins (Cbln2 and Cbln4) could not be demostrated.

As presently known, entire family of precerebellins is comprised of Cbln1, Cbln2, Cbln3 and Cbln4. These propeptides are expressed in the brain, predominantly in cerebellum, and belong to the $\mathrm{C}_{1} \mathrm{q}$ and tumour necrosis factor superfamily of signalling molecules $(4,43)$. Cbln1-derived peptide, CER and its truncated form des-Ser ${ }^{1}$-CER (desCER) were originally isolated from rat cerebellum $(1,2)$. It has been suggested that desCER is an apparent metabolite of CER, formation of which is probably catalysed by the serin aminopeptidase $(1,13)$. Recent data, however, demonstrate that precerebellins may be released from heterologous cells and may form heteromeric complexes with each other. These findings suggest that precerebellins are not only precursor proteins but may function also as signalling molecules. In this regard studies on cbln $1^{-/}$mice suggest that in cerebellum Cbln1 may function as an adhesive molecule regulating synaptic structures between parallel fibres and Purkinje cells $(11,12,44,45)$. Apart from a possible physiological role of 
precerebellins, it is expected that Cbln1-derived peptides would also be involved in regulating biological activity of various cell types.

Both CER and desCER are present at high concentrations in cerebellum and other brain regions. Moreover, these peptides were identified in such organs as alimentary tract, heart, kidney and endocrine glands $(4,13,14)$. However, no CER receptor was identified, although both CER and desCER exert a secretagogue action on catecholamine and aldosterone and cortisol/corticosterone secretion as well as on proliferative activity of adrenocortical cells $(15,46-50)$. Moreover, exogenous CER exerts inhibitory effects on thyroid function in the rat (51). In this regard, Takachashi et al (52) recently reviewed possible CER involvement in the regulation of neuroendocrine axis function. Furthermore, it has been found that CER increased cAMP release by human and rat adrenal slices and these effects were annulled by the protein kinase $\mathrm{A}$ inhibitor but not by phospholipase $\mathrm{C}$ and protein kinase $C$ inhibitors $(46,47)$. Thus, the above presented evidence suggests the possibility of direct, protein kinase A mediated CER action on secretory activity of adrenocortical cells.

Despite a distinct expression of Cbln1 and Cbln3 mRNA in rat osteoblast-like cells, we failed to demonstrate CER and desCER (concentrations $10^{-10}-10^{-6} \mathrm{M}$ ) effects on osteocalcin secretion and proliferative activity of these cells. The above findings suggest that CER, which theoretically would be derived from Cbln1, modulate neither differentiated (osteocalcin secretion) nor basic (proliferation) functions of cultured rat osteoblast-like cells. However, we have to consider also the other possible role of precerebellins in these cells. High expression of Cbln 1 and Cbln 3 in cultured ROB cells suggest that the cells may release precerebellins which are known to form heteromeric signalling complexes. In cerebellum, Cbln1 may function as an adhesive molecule regulating synaptic structures between parallel fibres and Purkinje cells $(11,12,44)$. Likewise, in the bone precerebellins could be responsible for spatial organization of the osteoblastic niches forming a specific bone microenvironment (53-55).

Our findings raise an intriguing hypothesis that precerebellins may be involved in regulating of spatial organization of osteoblastic niches in the bone. This assumption however requires further investigation.

\section{References}

1. Slemmon JR, Blacher R, Danho W, Hempstead JL and Morgan JI: Isolation and sequencing of two cerebellum-specific peptides. Proc Natl Acad Sci USA 81: 6866-6870, 1984.

2. Yiangou Y, Burnet P, Nikou G, Chrysanthou BJ and Bloom SR: Purification and characterisation of cerebellins from human and porcine cerebellum. J Neurochem 53: 886-889, 1989.

3. Wada $\mathrm{Ch}$ and Ohtani $\mathrm{H}$ : Molecular cloning of rat cerebellin-like protein cDNA which encodes a novel membrane-asociated glycoprotein. Mol Brain Res 9: 71-77, 1991.

4. Urade Y, Oberdick J, Molinar-Rode R and Morgan JI: Precerebellin is a cerebellum-specific protein with similarity to the globular domain of complement C1q B chain. Proc Natl Acad Sci USA 88: 1069-1073, 1991.

5. Pang Z, Zuo J and Morgan JI: Cbln3, a novel member of the precerebellin family that binds specifically to Cbln1. J Neurosci 20: 6333-6339, 2000.

6. Miura E, Iijima T, Yuzaki M and Watanabe M: Distinct expression of Cbln family mRNAs in developing and adult mouse brains. Eur J Neurosci 24: 750-760, 2006.
7. Muragaki Y, Shiota C, Inoue M, Ooshima A, Olsen BR and Ninomiya Y: Alpha I(VIII)-collagen gene transcripts encode a short-chain collagen polypeptide and are expressed by various epithelial, endothelial and mesenchymal cells in newborn mouse tissues. Eur J Biochem 207: 895-902, 1992.

8. Elima K, Eerola I, Rosati R, et al: The mouse collagen X gene: complete nucleotide sequence, exon structure and expression pattern. Biochem J 289: 247-253, 1993.

9. Petry F, Reid KB and Loos M: Molecular cloning and characterization the complementary DNA coding for the B-chain of murine C1q. FEBS Lett 258: 89-93, 1989.

10. Petry F, Reid KB and Loos M: Isolation, sequence analysis and characterization of cDNA clones coding for the $\mathrm{C}$ chain of mouse C1q. Sequence similarity of complement subcomponent C1q, collagen type VIII and type X and precerebellin. Eur J Biochem 209: 129-134, 1992.

11. Bao D, Pang Z and Morgan JL: The structure and proteolytic processing of Cbln1 complexes. J Neurochem 95: 618-629, 2005.

12. Yuzaki M: Cbln and Clq family proteins - new transneuronal cytokines. Cell Mol Life Sci (In press).

13. Burnet PWJ, Bretherton-Watt D, Ghatei MA and Bloom SR: Cerebellin-like peptide: tissue distribution in rat and guinea-pig and its release from rat cerebellum, hypothalamus and cerebellar synaptosomes in vitro. Neuroscience 25: 605-612, 1988.

14. Satoh F, Takahashi K, Murakami O, et al: Cerebellin and cerebellin mRNA in the human brain, adrenal glands and the tumour tissues of adrenal tumour, ganglioneuroblastoma and neuroblastoma. J Endocrinol 154: 27-34, 1997.

15. Rucinski M, Albertin G, Spinazzi R, Ziolkowska A, Nussdorfer GG and Malendowicz LK: Cerebellin in the rat adrenal gland: gene expression and effects of CER and (desSer $^{1}$ )CER on the secretion and growth of cultured adrenocortical cells. Int J Mol Med 15: 411-415, 2005.

16. Lundberg P, Lundgren I, Mukohyama H, Lehenkari PP, Horton MA and Lerner UH: Vasoactive intestinal peptide (VIP)/pituitary adenylate cyclase-activating peptide receptor subtypes in mouse calvarial osteoblasts: presence of VIP-2 receptors and differentiation-induced expression of VIP-1 receptors. Endocrinology 142: 339-347, 2001

17. Lundberg P, Lie A, Bjurholm A, Lehenkari PP, Horton MA, Lerner UH and Ransjö M: Vasoactive intestinal peptide regulates osteoclast activity via specific binding sites on both osteoclasts and osteoblasts. Bone 27: 803-810, 2000.

18. Bollag RJ, Zhong Q, Phillips P, Min L, Zhong L, Cameron R, Mulloy AL, Rasmussen H, Qin F, Ding KH and Isales CM: Osteoblast-derived cells express functional glucose-dependent insulinotropic peptide receptors. Endocrinology 141: 1228-1235, 2000.

19. Manolagas SC: Birth and death of bone cells: Basic regulatory mechanisms and implications for the pathogenesis and treatment of osteoporosis. Endocr Rev 21: 115-137, 2000.

20. Lagumdzija A, Bucht E, Stark A, Hulting AL and Petersson M: Arg-vasopressin increases proliferation of human osteoblast-like cells and decreases production of interleukin- 6 and macrophage colony-stimulating factor. Regul Pept 121: 41-48, 2004.

21. Lagumdzija A, Pernow Y, Bucht E, Gonon A and Petersson M: The effects of arg-vasopressin on osteoblast-like cells in endothelial nitric oxide synthase-knockout mice and their wild-type counterparts. Peptides 26: 1661-1666, 2005.

22. Elefteriou F: Neuronal signaling and the regulation of bone remodeling. Cell Mol Life Sci 62: 2339-2349, 2005.

23. Takeda S: Central control of bone remodeling. Biochem Biophys Res Commun 328: 697-699, 2005.

24. Fukumoto S, Kangawa K, Nagata K and Kojima M: Ghrelin directly regulates bone formation. J Bone Miner Res 20: 790-798, 2005.

25. Maccarinelli G, Sibilia V, Torsello A, et al: Ghrelin regulates proliferation and differentiation of osteoblastic cells. J Endocrinol 184: 249-256, 2005

26. Delhanty PJ, van der Eerden BC, van der Velde M, et al: Ghrelin and unacylated ghrelin stimulate human osteoblast growth via mitogen-activated protein kinase (MAPK)/phosphoinositide 3-kinase (PI3K) pathways in the absence of GHS-R1a. J Endocrinol 188: 37-47, 2006.

27. Karsenty G: Convergence between bone and energy homeostases: leptin regulation of bone mass. Cell Metab 4: 341-348, 2006.

28. Goto T, Nakao K, Gunjigake KK, Kido MA, Kobayashi S and Tanaka T: Substance P stimulates late-stage rat osteoblastic bone formation through neurokinin-1 receptors. Neuropeptides 41: 25-31, 2007 . 
29. Sato S, Hanada R, Kimura A, et al: Central control of bone remodeling by neuromedin U. Nat Med 13: 1234-1240, 2007.

30. Boden SC, McCuaig K, Hair G, et al: Differential effects and glucocorticoid potentiation of bone morphogenetic protein action during rat osteoblast differentiation in vitro. Endocrinology 137: 3401-3407, 1996.

31. Bodine PV and Komm BS: Tissue culture models for studies of hormone and vitamin action in bone cells. Vitam Horm 64: 101-151, 2002.

32. Kartsogiannis $\mathrm{V}$ and $\mathrm{Ng} \mathrm{KW}$ : Cell lines and primary cell cultures in the study of bone cell biology. Mol Cell Endocrinol 228: 79-102, 2004

33. Ziolkowska A, Rucinski M, Pucher A, Tortorella C, Nussdorfer GG and Malendowicz LK: Expression of osteoblast marker genes in rat calvarial osteoblast-like cells, and effects of the endocrine disrupters diphenylolpropane, benzophenone-3, resveratrol and silymarin. Chem Biol Interact 164: 147-156, 2006.

34. Ziolkowska A, Rucinski M, Tyczewska M, Belloni AS, Nowak M, Nussdorfer GG and Malendowicz LK: Down-regulation of the beacon gene expression in the regenerating rat adrenal cortex. Peptides 27: 3216-3219, 2006.

35. Mosmann T: Rapid colorimetric assay for cellular growth and survival: application to proliferation and cytotoxicity assays. J Immunol Methods 65: 55-63, 1983.

36. Albertin G, Carraro G, Parnigoto PP, Ziolkowska A, Malendowicz LK and Nussdorfer GG: Human skin keratinocytes and fibroblasts express adrenomedullin and its receptors, and adrenomedullin enhances their growth in vitro by stimulating proliferation and inhibiting apoptosis. Int J Mol Med 11: 635-639, 2003.

37. Tortorella C, Macchi C, Spinazzi R, Malendowicz LK, Trejter M and Nussdorfer GG: Ghrelin, an endogenous ligand for the growth hormone-secretagogue receptor, is expressed in the human adrenal cortex. Int J Mol Med 12: 213-217, 2003.

38. Ziolkowska A, Rucinski M, Di Liddo R, Nussdorfer GG and Malendowicz LK: Expression of the beacon gene in endocrine glands of the rat. Peptides 25: 133-137, 2004.

39. Ziolkowska A, Rucinski M, Tortorella C, Tyczewska M, Nussdorfer GG and Malendowicz LK: Cultured rat calvarial osteoblast-like cells are provided with orexin type 1 receptors. Int J Mol Med 20: 779-782, 2007.

40. Rucinski M, Ziolkowska A, Neri G, et al: Expression of neuromedins $\mathrm{S}$ and $\mathrm{U}$ and their receptors in the hypothalamus and endocrine glands of the rat. Int J Mol Med 20: 255-259, 2007

41. Albertin G, Rucinski M, Carraro G, Forneris M, Andreis P, Malendowicz LK and Nussdorfer GG: Adrenomedullin and vascular endothelium growth factor genes are overexpressed in the regenerating rat adrenal cortex, and AM and VEGF reciprocally enhance their mRNA expression in cultured rat adrenocortical cells. Int J Mol Med 16: 431-435, 2005.
42. Rucinski M, Ziolkowska A, Hochol A, et al: Estradiol and resveratrol stimulating effect on osteocalcin, but not osteonectin and collagen- $1 \alpha$ gene expression in primary culture of rat calvarial osteoblast-like cells. Int J Mol Med 18: 566-570, 2006.

43. Kishore U and Reid KB: C1q: structure, function, and receptors. Immunopharmacology 49: 159-170, 2000.

44. Hirai H, Pang Z, Bao D, Miyazaki T, Li L, Miura E, Parris J, Rong Y, Watanabe M, Yuzaki M and Morgan J.I: Cbln1 is essential for synaptic integrity and plasticity in the cerebellum. Nat Neurosci 8: 1534-1541, 2005

45. Iijima T, Miura E, Matsuda K, Kamekawa Y, Watanabe M and Yuzaki M: Characterization of a transneuronal cytokine family Cbln-regulation of secretion by heteromeric assembly. Eur J Neurosci 25: 1049-1057, 2007.

46. Mazzocchi G, Andreis PG, De Caro R, Aragona F, Gottardo L and Nussdorfer GG: Cerebellin enhances in vitro secretory activity of human adrenal gland. J Clin Endocrinol Metab 84: 632-635, 1999.

47. Albertin G, Malendowicz LK, Macchi C, Markowska A and Nussdorfer GG: Cerebellin stimulates the secretory activity of the rat adrenal gland: in vitro and in vivo studies. Neuropeptides 34: 7-11, 2000.

48. Malendowicz LK, Hochol A, De Caro R, Trejter M, Markowska A, Nussdorfer GG and Nowak M: Effect of cerebellin on the pituitary-adrenocortical function in adult rats and the proliferative activity of immature and regenerating rat adrenal cortex. Biomed Res 21: 85-88, 2000.

49. Hochol A, Macchi C, Majchrzak M, Ziolkowska A, Nussdorfer GG and Malendowicz LK: Comparison of the effects of cerebellin and cerebellin analog (Des-Ser1)-cerebellin on the secretion of rat adrenal cortex: in vitro and in vivo studies. Biomed Res 21: 217-219, 2000.

50. Hochol A, Neri G, Majchrzak M, Ziolkowska A, Nussdorfer GG and Malendowicz LK: Prolonged cerebellin administration inhibits the growth, but enhances steroidogenic capacity of rat adrenal cortex. Endocr Res 27: 11-17, 2001.

51. Malendowicz LK, Macchi C, Nussdorfer GG, Nowak KW, Ziolkowska A, Trejter M and Ginda W: Inhibitory effect of cerebellin on rat thyroid gland. Biomed Res 22: 99-101, 2001.

52. Takachashi K, Totsune K and Murakami O: Adrenocortical peptides: autocrine or paracrine regulators for the steroid hormone secretion or the cell proliferation? Exp Clin Endocrinol Diabetes 110: 373-380, 2002 .

53. Guillotin B, Bourget C, Remy-Zolgadri M, Bareille R, Fernandez P, Conrad V and Amédée-Vilamitjana J: Human primary endothelial cells stimulate human osteoprogenitor cell differentiation. Cell Physiol Biochem 14: 325-332, 2004

54. Zhu J and Emerson SG: A new bone to pick: osteoblasts and the haematopoietic stem-cell niche. Bioessays 26: 595-599, 2004.

55. Y in T and Li L: The stem cell niches in bone. J Clin Invest 116 : 1195-1201,2006. 